\title{
Mining the sparking rocks in the context of most frequent cases of methane ignition
}

\author{
Stanisław Trenczek, Rajmund Mann \\ Instytut Techniki Górniczej KOMAG, Poland \\ Eugeniusz Krause \\ Główny Instytut Górnictwa, Poland
}

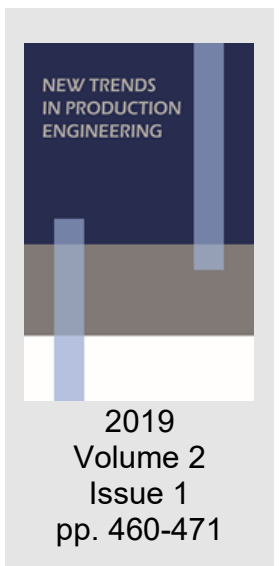

Date of submission to the Editor: 05/2019

Date of acceptance by the Editor: 08/2019

\section{INTRODUCTION}

Identification of the risk related to operations within a mining plant and taking the measures aimed at prevention and elimination of such risk by the employer is the general idea applied in underground mining operations (Ustawa, 2011). This means assessing and documenting the occupational risk during mining plant operations and applying the necessary preventive measures to reduce this risk. As a result, the employer must have appropriate materials and technical resources as well as properly organized mine servicing team to secure the safety of employees and the safety of mining plant operations.

Methane hazard is one of many hazards in underground coal mines. With the expansion of the scope of exploitation of coal seams to greater depths, the scale of this hazard increases. This concerns in particular the central and southern part of the Upper Silesian Coal Basin, where the risk of rock and gas outburst (Krause, 2017) and the methane release (Majcherczyk, Jakubów, 2017) is also becoming more and more frequent. However, the process of hard coal mining is always extremely important in the context of possible methane ignition.

\section{PRINCIPLES OF MECHANICAL MINING UNDER THE METHANE IGNITION HAZARD}

The current mining regulations (Rozporządzenie, 2011) require, beginning from the methane hazard category II or higher, the use of protection against methane ignition during the mining the compact rocks by a road header in the methane fields. Rock sparking is one of many dangerous methane ignition initiations (Trenczek, 2015).

The regulations (Rozporządzenie, 2011) require the appropriate selection of such measures. This is based on detailed analysis of the natural and technical conditions of the planned roadways. They must take into account the type of rocks in the face and the assumed range of their occurrence along the planned direction of the face advance, geological faults, and above all the ability of rocks to igniting methane sparking. In addition, they must include: 
- methane hazard characteristics, and in particular methane content, sources and places of methane emission, including the possibility of methane inflow from other roadways and faces, as well as the concentration of methane in the air and changes in this concentration occurring at different places in the roadway,

- possibility of the near roof methane accumulation,

- possible rock bursts and/or rock and gas outbursts,

- possibility of sudden methane releases from the near wall gobs.

The technical conditions of the planned roadways are also important elements of the analysis. That includes the method of methane detection, in particular the deployment of automatic methane sensors informing about the time of their startup and the type of equipment used, as well as the types of machines used for mining and the scope and frequency of inspections carried out by gasmen and mine supervision and ventilation division personnel.

The results of this analysis are entered into the technical project of the given mining operations.

The mining of compact rocks with high and medium sparking tendency is allowed only when the concentration of methane in the air flow discharged from the walls is not higher than $0.5 \%$ and at the same time the amount of discharged methane is not higher than $1 \mathrm{~m}^{3} / \mathrm{min}$, or higher than $0.5 \%$ or the amount of discharged methane is greater than $1 \mathrm{~m}^{3} / \mathrm{min}$, provided that the air flow rate in the wall is not lower than $1 \mathrm{~m} / \mathrm{s}$.

In turn, in roadways, mining the compact rocks of high and medium tendency to sparking caused by cutting with a road header, is acceptable when the methane concentration in the air is not higher than:

- $0.5 \%$ - in the case of measurements taken with an automatic methane sensor placed under the roof of the roadway at a distance not higher than $2 \mathrm{~m}$ from the face and causing the road header switch off,

- $1 \%$ - in the case of mining with a road header equipped with internal tools spraying system or other system reducing the risk of methane ignition, of which protection against ignition has been confirmed by tests.

Lack of near roof methane accumulation at a distance of up to $50 \mathrm{~m}$ from the location of the mined compact rocks is an additional condition.

\section{OVERVIEW OF WATER SPRAYING THE CUTTING DRUMS OF THE MINING MACHINE}

Amount of water consumed by the spraying installation for the mining machines is the main criterion taken into account during the installation designing process (Kalita, Prostański, 2015). To meet this criterion, different types of water stream dividers, which direct the stream to the cutting zone with high effectiveness, are used.

Usually, in longwall shearers (Winkler et al., 2015) double air-water spraying system (Prostański, 2013): external one from the arm and internal one from the cutting drum behind the tools, is used to control airborne dust concentration. 
Additionally, the water stream dispersed by nozzles has fire distinguishing properties. Thus, water consumption is reduced as the cooling water is used to supply spraying installation. The system of sectoral water spraying, which can be provided by directing the water stream to the area of deepening the cutting drum into the solid coal using the sectoral divider (Jeschner,1996), with the spraying water supply to the cutting area of each tool at the same time at the moment of its contact with the coal wall (due to use of opening valves in the tool holders which enable flow of the spraying medium under tool pressure) (Lemmes, 1993).

It is easy to notice that the overwhelming weight in various solutions is put on spraying the dust to reduce the dust concentration in the mine air. But, as it turns out, in the conditions of the dynamic methane hazard, which is manifested by more and more often rapid methane outflows of concentrations in air creating an inflammable/explosive mixtures, such spaying methods seem to be ineffective.

\section{ACCIDENTS WITH METHANE IGNITION WITHIN THE YEARS 2004-2019}

Within the last fifteen years, there were often accidents with methane ignition what is presented in the below Table 1.

Table 1 Cases of methane ignition within the years 2004-2019 with specification of ignition initiations

\begin{tabular}{|c|c|c|c|c|c|}
\hline $\begin{array}{l}\text { Ite } \\
\text { m }\end{array}$ & Mine & $\begin{array}{l}\text { Date of } \\
\text { accident }\end{array}$ & $\begin{array}{l}\text { Methane ignition } \\
\text { initiations }\end{array}$ & $\begin{array}{l}\text { Course of } \\
\text { action }\end{array}$ & $\begin{array}{c}\text { Acciden } \\
\text { ts } \\
\text { (f./h./I.) }\end{array}$ \\
\hline 1 & Budryk & 17.08.2004 & $\begin{array}{l}\text { Mechanical sparks } \\
\text { (from the mining machine) }\end{array}$ & ignition & $0 / 0 / 0$ \\
\hline 2 & Halemba & 03.03 .2005 & $\begin{array}{l}\text { Mechanical sparks } \\
\text { (from the mining machine) }\end{array}$ & ignition & $0 / 0 / 0$ \\
\hline 3 & Sośnica & 17.05.2005 & $\begin{array}{l}\text { Blasting operations } \\
\text { (for roof fall provocation) }\end{array}$ & $\begin{array}{l}\text { ignition } \\
\text { and fire }\end{array}$ & $0 / 0 / 0$ \\
\hline 4 & Staszic & 23.10 .2005 & $\begin{array}{l}\text { Smoking cigarettes } \\
\text { (rescuers during } \\
\text { construction of an isolation } \\
\text { dam) }\end{array}$ & ignition & $0 / 2 / 0$ \\
\hline 5 & Szczygłowice & 11.05.2006 & $\begin{array}{l}\text { Mechanical sparks } \\
\text { (from the mining machine) }\end{array}$ & ignition & $0 / 0 / 0$ \\
\hline 6 & Halemba & 21.11.2006 & $\begin{array}{l}\text { Electric arch } \\
\text { or electrostatic discharges, } \\
\text { or endogenous fire } \\
\text { or friction sparks in a gob }\end{array}$ & $\begin{array}{l}\text { ignition } \\
\text { and explosion } \\
\text { of methane } \\
\text { and coal dust }\end{array}$ & $23 / 0 / 1$ \\
\hline 7 & Halemba & 23.05.2007 & $\begin{array}{l}\text { Mechanical sparks } \\
\text { (from the mining machine) }\end{array}$ & ignition & $0 / 0 / 0$ \\
\hline 8 & Pokój & 28.07 .2007 & Blasting operations & ignition & $0 / 0 / 4$ \\
\hline 9 & Bielszowice & 02.09.2007 & Blasting operations & $\begin{array}{l}\text { ignition } \\
\text { and explosion }\end{array}$ & $0 / 0 / 0$ \\
\hline 10 & Budryk & 30.10 .2007 & $\begin{array}{l}\text { Mechanical sparks } \\
\text { (from the mining machine) }\end{array}$ & ignition & $0 / 0 / 0$ \\
\hline 11 & Mysłowice-Wesoła & 13.01 .2008 & Endogenous fire & $\begin{array}{l}\text { ignition } \\
\text { and explosion } \\
\text { of methane } \\
\text { and coal dust }\end{array}$ & $2 / 0 / 1$ \\
\hline 12 & Borynia & 04.06 .2008 & $\begin{array}{l}\text { Endogenous fire } \\
\text { or glue binder self-ignition } \\
\text { or electric arch }\end{array}$ & $\begin{array}{l}\text { ignition } \\
\text { and explosion }\end{array}$ & $6 / 5 / 12$ \\
\hline
\end{tabular}




\begin{tabular}{|c|c|c|c|c|c|}
\hline 13 & Zofiówka & 20.10 .2009 & $\begin{array}{l}\text { Mechanical sparks (from } \\
\text { the mining machine) }\end{array}$ & ignition & $0 / 0 / 0$ \\
\hline 14 & $\begin{array}{l}\text { Wujek } \\
\text { R. Śląsk }\end{array}$ & 18.09.2009 & electric arch (short-circuit) & $\begin{array}{l}\text { ignition } \\
\text { and explosion }\end{array}$ & $\begin{array}{l}20 / 25 / \\
9\end{array}$ \\
\hline 15 & $\begin{array}{l}\text { Mysłowice-Wesoła } \\
\text { R. Wesoła }\end{array}$ & 16.05 .2010 & Endogenous fire & twice ignition & $0 / 0 / 2$ \\
\hline 16 & $\begin{array}{l}\text { Murcki-Staszic } \\
\text { R. Staszic }\end{array}$ & 13.03.2011 & $\begin{array}{l}\text { Mechanical sparks } \\
\text { (from a mining machine) }\end{array}$ & ignition & $0 / 0 / 0$ \\
\hline 17 & Krupiński & 05.05 .2011 & $\begin{array}{l}\text { Mechanical sparks } \\
\text { (from a conveyor) }\end{array}$ & ignition & $3 / 9 / 2$ \\
\hline 18 & Bielszowice & 12.08 .2011 & $\begin{array}{l}\text { Mechanical sparks rubbing } \\
\text { against rock or mechanical } \\
\text { sparks (shearer -AFC - } \\
\text { roof support) or friction } \\
\text { sparks in a gob }\end{array}$ & ignition & $0 / 0 / 0$ \\
\hline 19 & $\begin{array}{l}\text { Murcki-Staszic } \\
\text { R. Staszic }\end{array}$ & 28.01.2013 & $\begin{array}{l}\text { Mechanical sparks } \\
\text { (from the mining machine) }\end{array}$ & ignition & $0 / 0 / 0$ \\
\hline 20 & $\begin{array}{l}\text { Murcki-Staszic } \\
\text { R. Staszic }\end{array}$ & 06.02 .2013 & $\begin{array}{l}\text { Mechanical sparks } \\
\text { (from the mining machine) }\end{array}$ & ignition & $0 / 0 / 0$ \\
\hline 21 & Rydułtowy-Anna & 25.02 .2013 & $\begin{array}{l}\text { Mechanical sparks } \\
\text { (from the mining machine) }\end{array}$ & ignition & $0 / 0 / 0$ \\
\hline 22 & $\begin{array}{l}\text { Knurów-Szczy- } \\
\text { głowice } \\
\text { R. Szczygłowice }\end{array}$ & 25.03 .2013 & $\begin{array}{l}\text { Mechanical sparks } \\
\text { (from the mining machine) }\end{array}$ & ignition & $0 / 0 / 0$ \\
\hline 23 & $\begin{array}{l}\text { Sośnica-Ma- } \\
\text { koszowy R. Sośnica }\end{array}$ & 13.12.2013 & Endogenous fire & $\begin{array}{l}\text { methane } \\
\text { ignition } \\
\text { and fire } \\
\end{array}$ & $0 / 0 / 4$ \\
\hline 24 & Bielszowice & 21.01.2014 & $\begin{array}{l}\text { Rock rubbing sparks over a } \\
\text { coal seam }\end{array}$ & ignition (crack) & $0 / 0 / 0$ \\
\hline 25 & Chwałowice & 19.07 .2014 & Blasting operations & ignition (crack) & $0 / 0 / 0$ \\
\hline 26 & $\begin{array}{l}\text { Mysłowice-Wesoła } \\
\text { R. Wesoła }\end{array}$ & 06.10 .2014 & Endogenous fire in a gob & $\begin{array}{l}\text { Ignition } \\
\text { and methane } \\
\text { explosion }\end{array}$ & $\begin{array}{l}5 / 15 / \\
10\end{array}$ \\
\hline 27 & $\begin{array}{l}\text { Mysłowice-Wesoła } \\
\text { R. Wesoła }\end{array}$ & 15.06.2015 & $\begin{array}{l}\text { Mechanical sparks } \\
\text { (rubbing of metal } \\
\text { components in a roof } \\
\text { support) }\end{array}$ & ignition (crack) & $0 / 0 / 0$ \\
\hline 28 & Sośnica & 11.07 .2015 & Blasting operations & ignition & $0 / 0 / 4$ \\
\hline 29 & Rydułtowy-Anna & 26.08 .2015 & Blasting operations & ignition (crack) & $0 / 0 / 0$ \\
\hline 30 & Krupiński & 12.03.2016 & $\begin{array}{l}\text { Mechanical sparks - } \\
\text { rubbing of the shearer } \\
\text { against wall in a fault area }\end{array}$ & ignition & $0 / 0 / 0$ \\
\hline 31 & Brzeszcze & 30.05 .2016 & $\begin{array}{l}\text { Mechanical sparks - rubbing } \\
\text { of the roadheader against } \\
\text { rock in a bottom part of the } \\
\text { roadway }\end{array}$ & ignition (crack) & $0 / 0 / 0$ \\
\hline 32 & Halemba-Wirek & 10.06.2016 & $\begin{array}{l}\text { Mechanical sparks - } \\
\text { rubbing of the shearer } \\
\text { against wall in a fault area }\end{array}$ & $\begin{array}{l}\text { methane } \\
\text { ignition } \\
\text { and fire } \\
\end{array}$ & $0 / 0 / 0$ \\
\hline 33 & $\begin{array}{l}\text { Murcki-Staszic } \\
\text { R. Murcki }\end{array}$ & 18.10.2016 & unknown & $\begin{array}{l}\text { ignition nd } \\
\text { methane } \\
\text { explosion } \\
\text { in the } \\
\text { ventilation } \\
\text { shaft }\end{array}$ & $1 / 0 / 0$ \\
\hline 34 & Budryk & 11.03.2017 & $\begin{array}{l}\text { Mechanical sparks - } \\
\text { rubbing against rock mined } \\
\text { by roadheader during run- } \\
\text { of-mine loading }\end{array}$ & ignition & $0 / 0 / 0$ \\
\hline 35 & Brzeszcze & 19.07.2017 & $\begin{array}{l}\text { Mechanical sparks - } \\
\text { rubbing of the shearer's } \\
\text { cutting drum against waste } \\
\text { rock inserts found locally } \\
\text { in a side wall }\end{array}$ & ignition & $0 / 0 / 0$ \\
\hline
\end{tabular}




\begin{tabular}{|c|l|l|l|l|l|}
\hline 36 & $\begin{array}{l}\text { Borynia-Zofiówka- } \\
\text { Jastrzębie } \\
\text { R. Zofiówka }\end{array}$ & 24.10 .2017 & $\begin{array}{l}\text { Mechanical sparks - } \\
\text { rubbing of the roadheader } \\
\text { against rock in a roadway } \\
\text { face }\end{array}$ & $\begin{array}{l}\text { methane } \\
\text { ignition } \\
\text { and fire }\end{array}$ & $0 / 0 / 0$ \\
\hline 37 & $\begin{array}{l}\text { Borynia-Zofiówka- } \\
\text { Jastrzębie } \\
\text { R. Zofiówka }\end{array}$ & 07.06 .2018 & $\begin{array}{l}\text { Mechanical sparks - } \\
\text { rubbing of the shearer's } \\
\text { cutting drum against rock } \\
\text { (sandstone) in the area of } \\
\text { local fault }\end{array}$ & ignition (crack) & $0 / 0 / 0$ \\
\hline 38 & $\begin{array}{l}\text { Murcki-Staszic } \\
\text { R. Staszic }\end{array}$ & 29.06 .2018 & $\begin{array}{l}\text { Mechanical sparks - } \\
\text { rubbing of the shearer's } \\
\text { cutting drum against rock } \\
\text { (sandstone) in the area of } \\
\text { local fault }\end{array}$ & ignition (crack) & $0 / 0 / 0$ \\
\hline 40 & $\begin{array}{l}\text { Knurów- } \\
\text { Szczygłowice } \\
\text { R. Szczygłowice }\end{array}$ & 25.01 .2019 & $\begin{array}{l}\text { Blasting operations in } \\
\text { roadway face to mine solid } \\
\text { coal }\end{array}$ & ignition & $0 / 0 / 0$ \\
\hline KWK Budryk & 23.04 .2019 & $\begin{array}{l}\text { Mechanical sparks - } \\
\text { rubbing the roadheader's } \\
\text { cutterhead against a } \\
\text { sandstone in roadway face } \\
\text { floor }\end{array}$ & ignition & $0 / 0 / 0$ \\
\hline TOTAL & $\begin{array}{l}\text { Mechanical sparks - } \\
\text { rubbing the roadheader's } \\
\text { cutterhead against } \\
\text { a sandstone in roadway } \\
\text { face floor }\end{array}$ & ignition & $0 / 0 / 0$ \\
\hline & KWK Budryk & 26.04 .2019 & $60 / 56 / 49$ \\
\hline
\end{tabular}

Source: (WUG, 2019)

From the above table it results that there were 41 accidents associated with methane ignition. In one case there was not possible to determine initiations of methane ignition (Table 1, item 33), in three cases the initiations were not determined clearly (Table 1 - items $6,12,18$ ). In other 37 accidents in 32 cases there were technical initiations. Sparks from mechanical rubbing against rock, including those from a longwall shearer - 15 cases, from a road header -7 cases.

- Assuming that cutting of rocks prone to generation of sparks igniting the methane were realized when meeting the given regulations (Rozporządzenie, 2011) - concerning the following aspects:

- methane concentration in outlet stream of air from the longwall as well as volume of discharged methane keeping the proper airflow in the longwall,

- methane concentration in air in the face of the developed roadway - not exceeding the given criterial values adequate to the methods for taking measurements by the automatic methane meter as well as to the type of internal spraying of tools or to other system limiting the risk of methane ignition,

- lack of near-roof methane accumulation in a distance up to $50 \mathrm{~m}$ from the area of cutting the compact rocks ,

- efficient spraying during operation of cutter heads,

- theoretically methane ignition should not happen. Thus, we can conclude that probably there should be another element, which is difficult to be foreseen and it means that cutting the rocks prone to sparking is dangerous . 


\section{METHANE IGNITION FROM FLOOR ROCKS SPARKING}

Two methane ignitions took place within 3 days in the face of Roadway B-13 in the seam 401 of thickness from $1.85 \mathrm{~m}$ to $2.6 \mathrm{~m}$ at level $1050 \mathrm{~m}$. (WUG, 2019), in extremely different technical and technological conditions, but in identical geological and mining conditions.

The roadway was developed at distance $266 \mathrm{~m}$, the target length is $1365 \mathrm{~m}$. In this place the seam 401 was deposited at inclination about $9^{\circ}$. At the site of this roadway the seam 401 was classified to IV of methane hazard - methane content of the seam 401 in the area of the developed roadway reached 5.622 $\mathrm{m}^{3} \mathrm{CH}_{4} / \mathrm{Mg}_{\mathrm{csw}}$ - to I degree of bumping hazard, to class $\mathrm{B}$ of coal dust explosion hazard and to I degree of water hazard. Roadway B-13 in seam 401 was classified to "c" degree of methane explosion hazard and along $350 \mathrm{~m}$ of Roadway B-13 panel, the seam 401 was classified to III degree of gases and rocks outburst. In a floor of the seam 401, a layer of clay shale with local interlayers of sandy shale or sandstone of total thickness of about $15.0 \mathrm{~m}$, was deposited and in the floor a layer of clay shale of thickness about $0.7 \mathrm{~m}$ with underlaying sandstone layer of thickness up to $15.8 \mathrm{~m}$ which is prone to methane igniting sparking, when mined mechanically, was deposited. So, under the roadway floor, at a distance $2 \mathrm{~m}$ form the face, an automatic methane meter, which switches off the road header, when methane content exceeds $1.0 \%$, was installed.

The roadway was developed using the AM-75-Ex-S road header, equipped with internal water spraying system integrated with cutter heads as well as with external system.

The roadway was ventilated using a combined vortex ventube system with an elastic ventube line of diameter $1200 \mathrm{~mm}$ ended with a vortex ventube, air was fed with flowrate equal to about $650 \mathrm{~m}^{3} / \mathrm{min}$. Additionally, the sucking ventube of diameter $600 \mathrm{~mm}$ equipped with the dust controller was installed in the face. The first methane ignition took place on 23 April 2019. During this accident the following rock formations were present (from the roadway floor):

- sandstone highly prone to methane igniting sparking, of thickness from 0.15 $\mathrm{m}$ at the North side and up to $0.45 \mathrm{~m}$ at the South side,

- clay shale layer of thickness $0.7 \mathrm{~m}$, laying on sandstone,

- coal of the seam 401 - thickness $2.33 \mathrm{~m}$,

- again a clay shale, filling the rest of the roadway cross-section.

During this shift, automatic methane sensors, installed in the face, recorded 5 exceedances of methane concentration limit up to the 1.1\%. About 10:40 a.m. - during solid coal cutting at the roadway face with presence of sandstone near the floor at the face North side - methane was ignited. Flame of burning methane was extinguished after about $10 \mathrm{~min}$. by the workers being in this area with use of 11 powder fire extinguishers.

Automatic methane sensors installed within the Roadway B-13 in the seam 401 did not record exceedance of methane concentration threshold limit neither before the accident nor during and after the accident. However, carbon 
monoxide analyser placed in air stream from the developed roadway recorded on 11:00-11:05 a.m. increase of $\mathrm{CO}$ concentration to over $26 \mathrm{ppm}$, with maximum 29 ppm. Such $\mathrm{CO}$ concentration was a result diesel drive train operating in this area at this time. However, participation of $\mathrm{CO}$ from the methane burning process, during the accident, cannot be excluded.

Form the tests conducted by Okręgowy Urząd Górniczy (District Mining Office) in Gliwice it results that sparking caused by mechanical cutting of sandstone, highly prone to methane igniting sparking, was the most probable reason of methane ignition in the face of Roadway B-13 in the seam 401. Cutting by road header with not fully efficient internal spraying system integrated with cutter heads increased the methane ignition hazard.

The first methane ignition took place on 26 April 2019 in the same geological and mining conditions in relation to the first ignition (Informacja WUG, 26.04.2019). After a break in operation required to eliminate the failures and implementation of new measures after the first ignition, roadway development was continued. Equipping the road header with an additional spraying installation with a valve activated by the operator to enable directing the water stream to the places of cutting the prone to sparking rocks was one of such measures.

In this day on "B" shift, after drilling 2.25 m of roadway at 9:10 p.m., during cutting the sandstone present at floor of North side of the face - cross-section area of the driven roadway face the same as in the previous case - methane released from the slot was ignited. Flame of burning methane was extinguished by the workers being in this area with use of three powder fire extinguishers. Automatic gas sensors - methane metres and carbon monoxide analysers - did not record any exceedances of gas concentration limits neither before the accident nor during and after the accident, what confirmed the assumption that $\mathrm{CO}$ in the first ignition was recorded due to operation of diesel railway.

Form the tests conducted by Okręgowy Urząd Górniczy (District Mining Office) in Gliwice it results that (Informacja WUG, 26.04.2019, Informacja WUG, 23.04.2019):

- cutting operation were realized with fully effective spraying installations - road header one and additional one,

- methane concentration parameters required by the regulations were maintained in the roadway face,

- parameters of ventilation, separate combined ventilation as well as additional ventilation were correct,

- sparking caused by cutting the sandstone prone to methane ignition sparking was the most probable reason of ignition of methane released from a slot in the Roadway B-13 in the seam 401.

From the descriptions of the accidents given above, it appears that the geological and mining conditions had a decisive impact on methane ignition. 


\section{INDIVIDUAL APPROACH TO THE CONDITIONS OF CUTTING THE ROCKS PRONE TO SPARKING}

Regulations on the mining of sparking rocks with a road header (Rozporządzenie, 2011) require limiting the risk of methane ignition against rock sparks, what means that the legislator does not exclude the possibility of methane ignition while mining the sparking rocks. Because such a risk always exists, risk reduction should be realized by applying the safety measures concerning the following actions:

- ventilation and control of the methane hazard, i.e.:

o auxiliary ventilation devices diluting the methane in the roadway face or protecting against local methane accumulation,

o independent roadway ventilation eliminating the possibility of methane inflow from other roadways or from other methane sources,

o intensification of methane removal,

○ arranging additional methane measuring points by gasmen, front miners and mine supervising personnel,

o increasing the frequency of taking measurements of methane concentration and adaptation of the safety measure to the level of current hazard,

o drilling the exploratory boreholes in the case of approaching to the expected geological faults;

- elimination of mechanical sparks during cutting the compact rocks of high and medium tendency to sparking i.e.:

- additional spraying devices and nozzles,

o equipping the roadway faces with the devices which enable to immediate pouring the mined rocks with water, especially by using the fire-fighting hoses,

o adaptation of ripping to the type of rocks in a roof or floor to eliminate cutting the compact rocks;

- deciding about increased control of mining operations by the mine supervisory personnel i.e. controlling the following conditions:

o ventilation,

○ methane hazard,

- methane concentration measuring system,

- cutterhead condition regarding the effectiveness of spraying installation.

Before the second of the described accidents, such an analysis was made, additional rigors were introduced - what had already been mentioned - what certainly reduced the risk of methane re-ignition, and then the roadway development was restarted. Since, however, the methane was re-ignited, continuation of roadway development depended on the decision of the OUG Director in Gliwice and on development - by the expert in mining operations in the scope of group XV methane and coal dust explosion hazard - such a method for roadway development that would eliminate methane ignition. 
Finally the report (Opracowanie, 2019) was developed, which included once again the following detailed analyses:

- mining and geological conditions in the seam 401 part B,

- changes in a level of methane as well as rocks and gases outburst hazard in the seam 401,

- cases of methane ignition accidents during development of the Roadway B13 , together with assessment of impact of methane content in the seam 401 as well as impact of waste rock deposited around the Roadway,

- of arrangements regarding the reasons of methane ignition as well as accompanying circumstances,

- of the scope and effects of prophylactic work implemented after methane ignition,

- conditions and level of the hazards present during previous roadway development in this seam located on North to the Roadway B-13,

- verification of the seam 401 classification correctness regarding the rocks and gases outburst hazard,

- of other methods for identification and forecasting the gases and rock outbursts hazard,

- agreements regarding the application of the rigors, those resulting from the regulations and those regarding additional ventilation of near-the-face zone.

Only after such a thorough analysis the following actions were possible:

- verification of the technical project for the Roadway B-13 development,

- determination of new threshold limits to classify the seam 401 to III degree of gases and rock outbursts hazard - from $266 \mathrm{~m}$ of the roadway panel,

- determination of principles for Roadway B-13 development eliminating the chance of methane ignition,

- determination of the Roadway B-13 development profile,

- determination of rules for restarting the Roadway B-13 development,

- determination of the scope of preparation work for restarting the development of Roadway B-13.

In the context of the aforementioned necessity (Rozporządzenie, 2011) of using the measures limiting the possibility of methane ignition from mining the rocks prone to sparking, it is worth mentioning that the circumstances set out in the Report (Opracowanie, 2019) related to these methane ignitions, which were as follows:

- high saturation of sandstone, deposited within the Roadway B-13 crosssection as well as below the roadway floor, with methane,

- intensive methane desorption and its outflow from the face under the pressure $0.05 \mathrm{MPa}$, which blown out the spraying water from the cutterhead surroundings as well as water from additional spraying installation,

- stress release of sandstone layer in the Roadway B-13 floor and ahead of the developed roadway face, what caused a slot methane outflow mainly from sandstone of the face front, 
- partial destruction of closed sandstone porosity, in which there is a high gas pressure, which causes its slot flow into the roadway, where there is lower pressure, close to the atmospheric pressure,

- slot cumulative outflow of small methane volume from the face front of its high content - about $65 \%$ what was confirmed by:

- lack of exceedance of accepted methane concentration in the area of its measurements in the roadway face,

- lack of recording carbon monoxide concentration in outflow air stream to which air entered from the Roadway B-13.

\section{CONCLUSIONS}

In the central and southern part of the Upper Silesian Coal Basin methane outflows are reported more and more often. The outflows are characterized by a small volume of methane and its high concentration, often leading to methane ignitions from mining the sparking rock with a road header.

The cutterhead spraying systems are usually designed to consume as little water as possible while maintaining high efficiency of controlling the generation of dust clouds, which means that they are intended for control of mine airborne dust.

Over the past 15 years, 41 methane ignition related accidents took place, of which 22 methane ignition accidents happened during mining sparking rock with a road header.

An example of methane ignition in specific geological and mining conditions and applying additional measures to reduce the risk of methane ignition during the mining of sparking rock shows that despite the full technical and technological protection of mining operations during roadways development, there may be other factors that allow methane ignition.

The analysis of all conditions, including the technical and technological ones, after ignitions of methane in the same face, showed that there are the following circumstances favoring the methane ignition:

- high volume saturation of sandstone layer by methane,

- increased desorption of methane and its slot high pressure outflow from the face, resulting in blowing out the spraying water surrounding the cutterhead and water directed there from the additional spraying device,

- sandstone layer pressure release near the face of the developed roadway, contributes to the partial destruction of closed sandstone porosity, in which there is high gas pressure, causing its slotted flow to the roadway, where the pressure is lower (close to the atmospheric pressure),

- a small volume of highly concentrated methane - about $65 \%$ - with a cumulative methane slot outflow.

In the case of mining the sparking rocks, an individual approach to a given case is necessary, regardless of whether it concerns the roadway development or the mining of the seam. 
It seems reasonable to undertake further research work and develop a spraying system aimed also at preventing methane ignition caused by sparks from the mined rock and appearing simultaneously with a dynamic outflow of methane from the slots of mined rock.

\section{REFERENCES}

Dane Wyższego Urzędu Górniczego - Stan bezpieczeństwa pracy w górnictwie - lata 2004-2019. Opracowanie WUG, dostępność: http://www.wug.gov.pl/index. php?bhp - 08.06.2019 r.

E. Jeschner, (1996): Poprawa bezpieczeństwa pracy w niemieckim górnictwie węgla kamiennego przez zastosowanie powietrzno-wodnego systemu zraszania firmy PAURAT. Materiały konferencji nt. „Nowoczesne metody drążenia wyrobisk korytarzowych z uwzględnieniem aspektów bezpieczeństwa pracy". Szczyrk, maj 1996 r. Wyd. CMG KOMAG, Gliwice.

M. Kalita, D. Prostański, (2015): Koncepcja systemu zraszania sektorowego zanożowego głowicy urabiającej kombajnu chodnikowego. Przegląd Górniczy, Nr 7 , str. 43-48

E. Krause, (2007): Wpływ uwarunkowań geologicznych i gazowych na kształtowanie się zagrożenia wyrzutami gazów i skał w Górnośląskim Zagłębiu Węglowym. Prace Naukowe GIG - Górnictwo i Środowisko, Nr 2 str. 65-74

F. Lemmes, (1993): Zraszanie wewnętrzne na organach urabiających kombajnów chodnikowych. Materiały Konferencji KOMTECH nt. „Zwalczanie zapylenia w wyrobiskach korytarzowych i komorowych". Szczyrk,

T. Majcherczyk, A. Jakubów, (2007): Zagrożenie gazodynamiczne w kopalniach Jastrzębskiej Spółki Węglowej S.A. Górnictwo i Geoinżynieria, Zeszyt 3/1, s. 371384

Opracowanie Rzeczoznawcy ds. ruchu zakładu górniczego pn. „Zweryfikowanie i zaopiniowanie Projektu technicznego drążenia chodnika B-13 w pokładzie 401 ze szczególnym uwzględnieniem występującego zagrożenia metanowego, oraz ustalenie zasad drążenia tego wyrobiska eliminujących możliwość zapalenia się metanu przy uwzględnieniu szczelinowego wypływu metanu z tarczy przodka drążonego wyrobiska", (2019). Dokumentacja GIG KD Barbara w Mikołowie. Katowice - Mikołów, niepublikowana

Prostański, D. (2013). Use of Air-and-Water Spraying Systems for Improving Dust Control in Mines. Journal of Sustainable Mining, Volume 12, Issue 2, Pages 2934

Rozporządzenie Ministra Energii z dnia 23 listopada 2016 r. z dnia 23 listopada 2016 r. w sprawie szczegółowych wymagań dotyczących prowadzenia ruchu podziemnych zakładów górniczych. Dz. U. z 2017 r. poz. 1118

S. Trenczek, (2015): Zapalenia i wybuchy metanu w kontekście inicjałów związanych z zagrożeniami technicznymi i naturalnymi. Przegląd Górniczy, Nr 2, s. 87-92

Ustawa z dnia 9 czerwca 2011 r. - Prawo geologiczne i górnicze. Dz. U. z 2011 r. Nr 163 poz. 981 z późn. zm.

T. Winkler, E. Pieczora, M. Marcińczyk, J. Kozłowski, (2015): Innowacyjne rozwiązanie kombajnu KSW-800NE efektem współpracy KOMAG-u i KOPEX-u. Maszyny Górnicze, Nr 3, str. 22-28

Informacja WUG o zapaleniu metanu w KWK Budryk w dniu 26.04.2019 r. dostępność: http://www.wug.gov.pl/bhp/26_04_2019-07.06.2019 r.

Informacja WUG o zapaleniu metanu w KWK Budryk w dniu 23.04.3019 r. dostępność: http://www.wug.gov.pl/bhp/23_04_2019-07.06.2019 r. 


\section{Abstract.}

The article presents the principles of safe cutting of rocks prone to generate igniting methane sparks. A list of methane ignitions and explosions from the sparking of rocks caused by cutting with road header was given. Unusual case of methane ignition in conditions of full technical and technological protection of roadway development is discussed. In conclusions, the importance of an individual approach to geological and mining conditions in the case of the need to cut sparking rocks was emphasized.

Keywords: sparks, methane ignition, sparking rocks, protection 